\title{
ANALISIS PENGENDALIAN KUALITAS PRODUK TELUR DI PERSADA FARM DUSUN ARGOPENI DESA SUDIMORO KECAMATAN SRUMBUNG KABUPATEN MAGELANG
}

\author{
Analysis The Quality Controlof Chicken Egg Products In Persada Farm \\ Argopeni Hamlet Sudimoro Vilage Srumbung Sub-District Magelang District \\ Indah Kuswardani*, Ni Made Suyastiri YP, dan Heni Handri Utami \\ Program Studi Agribisnis Fakultas Pertanian \\ Universitas Pembangunan Nasional Veteran Yogyakarta \\ J1. SWK 104, Condong Catur Yogyakarta Indonesia 55283 \\ *Email korespondensi : indahkuswardani99@gmail.com
}

Diterima tanggal : 10 Juni 2020 ; Disetujui tanggal : 28 Juni 2020

\begin{abstract}
The objectives of this study were to find out the dominant level damaged on chicken egg products, analyze the level damage limits of chicken egg products and describe factors that cause chicken egg damage, which included humans, methods, machinery, raw materials, and the environment. The research method was descriptive with the implementations method was survey. The respondents determined by purposive method. The data used primary data and secondary data. methods of collecting data on observation, interviews, and documentation. Analyzed techniqu to find out the dominant level damaged used checking sheet, histogram, and paretto diagrams, analyzed technique to analyzed the damage limits used p-chart, and analyzed technique to describe factors that cause chicken egg damage used fishbone diagrams. The results of the study showed that the damaged of chicken egg products dominted by white egg products with total percentage was 3,4\% white eggs. Controlling of chicken egg damaged level was out of control cause the damage was more than the company control limit 5\%. Human (negligence and indiscipline of employees), method (laying the number of chickens in a battery cage), machinery (chicken cages not fit for use and damaged feed place), raw material (eggs stepped on by chickens, cannibal between chickens, chickens eat eggs) and environment (rat pests, weather changes and cage hygiene) were factors that influence chicken eggs damage.
\end{abstract}

Keywords : Chicken Egg, Controlling, Quality, The Level Of Damage

\begin{abstract}
ABSTRAK
Tujuan dari penelitian ini adalah untuk mengetahui tingkat kerusakan dominan pada produk telur ayam, menganalisis batas tingkat kerusakan produk telur ayam dan mendeskripsikan faktor-faktor yang menyebabkan kerusakan telur ayam yang meliputi tenaga kerja, metode, mesin, bahan baku, dan lingkungan. Metode penelitian adalah deskriptif dengan metode pelaksanaan survei. Responden ditentukan dengan metode purposive. Data yang digunakan adalah data primer dan data sekunder. Metode pengumpulan data observasi, wawancara, dan
\end{abstract}


dokumentasi. Teknik analisis untuk mengetahui tingkat kerusakan dominan menggunakan lembar periksa, histogram dan pareto, teknik analisis untuk menganalisis batas tingkat kerusakan menggunakan peta kendali-P dan teknik analisis untuk mendeskripsikan faktor-faktor yang menyebabkan kerusakan telur ayam menggunakan diagram tulang ikan. Hasil penelitian menunjukkan bahwa kerusakan produk telur ayam didominasi oleh produk telur putih dengan persentase total adalah 3,4\% telur putih. Pengendalian tingkat kerusakan telur ayam di luar kendali menyebabkan kerusakan lebih dari batas kendali perusahaan 5\%. manusia (kelalaian dan ketidakdisiplinan karyawan), metode (meletakkan jumlah ayam dalam kandang baterai), mesin (kandang ayam tidak cocok untuk digunakan dan tempat pakan rusak), bahan baku (telur diinjak oleh ayam, kanibal antara ayam, ayam memakan telur) dan lingkungan (hama tikus, perubahan cuaca dan kebersihan kandang) adalah faktor yang mempengaruhi kerusakan telur ayam.

Kata kunci : Kualitas, Pengendalian, Telur Ayam, Tingkat Kerusakan

\section{PENDAHULUAN}

Pada saat ini pengembangan usaha peternakan ayam petelur di Indonesia menjadi sebuah industri yang memiliki komponen lengkap dari sektor hulu sampai ke hilir dan memiliki prospek yang cukup meyakinkan, dimana pengembangan usaha ini memberikan kontribusi nyata dalam pembangunan pertanian. Hal ini dikarenakan telur ayam merupakan salah satu bahan makanan pokok sumber protein hewani yang banyak diminati oleh masyarakat Indonesia. Keberhasilan usaha ini ditentukan oleh produktivitas dan keuntungan finansial, dimulai dari produksi telur hingga ke pemasaran. Upaya untuk meningkatkan produktivitas dengan memperhatikan seperti menerapkan efisiensi usaha, meningkatkan kualitas produk, menjamin kontinuitas suplai dan sesuai permintaan pasar sehingga kualitas produk telur dapat bersaing dengan produk telur dari negara lain.

Menurut Ginting (2007) Pengendalian kualitas merupakan suatu sistem verifikasi dan penjagaan/perawatan dari suatu tingkat/derajat kualitas produk atau proses yang dikehendaki dengan perencanaan yang seksama, pemakaian peralatan yang sesuai, inspeksi yang terus menerus serta tindakan korektif bilamana diperlukan. Jadi pengendalian kualitas tidak hanya kegiatan inspeksi ataupun menentukan apakah produk itu baik (accept) atau jelek (reject). Pengedalian kualitas dilakukan mulai dari proses input informasi/bahan baku dari pihak 
Kuswardani et.al., Analisis Pengendalian Kualitas Produk Telur Di Persada Farm..

marketing dan purchasing hingga bahan baku itu diolah di pabrik (fase transformasi) yang akhirnya dikirim ke pelanggan. Pengendalian kualitas yang dilakukan dalam usaha perternakan untuk produk telur ayam dengan melalui manual visual inspection. Pengelompokan telur selama ini dengan urutan grading kerusakan pada telur. Pendeteksi kerusakan pada telur yang dilakukan oleh manusia dengan melihat warna cangkang telur. Human error pada saat proses inspeksi yang harus diperhatikan dan direduksi karena proses inspeksi merupakan proses penentuan produk. Oleh karena itu, pengendalian kualitas dapat dilakukan mulai dari manajemen pemeliharaan ayam ras petelur selama proses produksi berlangsung sampai ayam memproduksi telur yang akan dipasarkan kepada konsumen. Proses ini membantu perusahaan dalam menjaga konsistensi kualitas hasil produksi menjadi lebih baik.

Persada Farm sebagai salah satu usaha yang bergerak dalam bidang peternakan ayam ras petelur, terletak di Dusun Agropeni Desa Sudimoro, Kecamatan Srumbung, Kabupaten Magelang. Persada Farm berdiri sejak tahun 1988 hingga saat ini perusahan mampu menghasilkan puluhan ribu telur ayam perhari dengan bibit ayam sejumlah 400 ribu ekor ayam yang dimiliki. Telur ayam yang hasilkan di Persada Farm merupakan produk telur yang berkualitas dan selalu dalam kondisi baik, hal ini dikarenakan produk telur tersebut tidak lama disimpan dalam waktu lama digudang melainkan Persada Farm selalu memasarkannya secara berkala. Sehingga tidak ada telur yang menunggu dan tersimpan lama digudang untuk menjaga kualitas telur itu sendiri. Berbagai program pengendalian kualitas dilakukan oleh perusahaan sehingga menghasilkan telur yang sesuai dengan standar kualitas yang telah ditentukan. Akan tetapi, masih terdapat telur yang memiliki kualitas buruk. Sebagaimana diketahui bahwa sebagian besar produk telur dari Persada Farm di pasarkan di daerah Yogyakarta, Jakarta, dan Kebumen.

Pentingnya melakukan pengawasan dan pengendalian tingkat kerusakan produk pada pelaksanaan produksi masih terdapat produk yang mengalami kerusakan. Persada Farm telah melakukan pengendalian tingkat kerusakan produk namun pengendalian tersebut hanya dilakukan pada tahap awal dan akhir produksi. 
Hal ini yang menyebabkan masih terjadinya kerusakan pada produk telur karena tidak adanya pencegahan dan solusi untuk perbaikan. Kriteria produk yang dinyatakan rusak, yaitu telur retak, telur pecah dan telur berwarna putih. Untuk mengukur tingkat kerusakan, Persada Farm menetapkan bahwa dalam satu kali produksi, produk telur ayam yang sesuai dengan standar kualitas adalah telur baik dengan kriteria telur berwarna coklat terang, berukuran normal tidak besar dan tidak terlalu kecil. Adapula dalam produksi terdapat produk yang tidak sesuai dengan standar tersebut, maka telur ayam dianggap memiiki kualitas rendah. Telur ayam yang rusak atau memiliki kualitas rendah dengan kriteria telur berwarna putih, telur retak, dan telur pecah. Persada Farm telah menetapkan standar tingkat kerusakan produk telur sebesar 5\% dengan standar tersebut Persada Farm dapat menekan atau mengurangi volume kerusakan, menjaga atau menaikan kualitas, meminimalisir kerugian, meningkatkan keuntungan dan menjaga atau menaikan comporate image. Penelitian ini bertujuan untuk mengetahui tingkat kerusakan produk yang paling dominan yang terjadi pada produk telur ayam di Persada Farm, menganalisis batas kendali tingkat kerusakan produk di Persada Farm, dan mendeskripsikan faktor-meliputi tenaga kerja, metode, mesin, bahan baku, dan lingkungan yang menyebabkan kerusakan produk telur ayam di Persada Farm.

\section{METODE PENELITIAN}

Metode dasar penelitian yang digunakan adalah metode deskriptif, untuk metode pelaksanaan menggunakan survei. Metode penentuan lokasi menggunakan metode purposive sampling, digunakan di Persada Farm karena Persada Farm merupakan usaha peternakan ayam ras petelur terbesar di tingkat Dusun Agropeni dibandingkan usaha peternakan ayam ras petelur lainnya.. Metode penentuan responden menggunakan metode purposive yang menjadi responden adalah pemilik, manajer farm, dan mandor karena mereka yang memahami seluk beluk kegiatan proses produksi di Persada Farm. Macam dan sumber data yaitu data

primer dan data sekunder dengan teknik pengumpulan data menggunakan observasi, wawancara, dan dokumentasi. 
Kuswardani et.al., Analisis Pengendalian Kualitas Produk Telur Di Persada Farm..

Mengetahui tingkat kerusakan dominan pada produk telur ayam

\section{Lembar Pemeriksaan (Check Sheet)}

Data yang diperoleh dari Persada Farm yaitu data produk telur ayam dan kerusakan produk telur ayam dari Bulan Agustus 2018 hingga Juli 2019, kemudian diolah dan disajikan dalam bentuk tabel secara terstruktur.

\section{Diagram Histogram}

Data yang diperoleh dari Persada Farm mengenai jumlah produk telur ayam maupun jumlah produk baik dan kerusakan produk telur ayam dari Bulan Agustus 2018 hingga Juli 2019. Data diolah menjadi bentuk diagram batang yang menunjukan tabulasi dari data yang diatur berdasarkan ukurannya. Tujuannya untuk mempermudah dalam menjelaskan dan menganalisi data lebih singkat.

\section{Diagram Pareto}

Data yang diperoleh dari Persada Farm mengenai jumlah kerusakan produk telur ayam dari Bulan Agustus 2018 hingga Juli 2019. Data diolah menjadi bentuk grafik batang terbagi berdasarkan jenis kerusakan masing-masing dari data tertinggi di sebelah kiri ke yang paling kecil di sebelah kanan.

\section{Menganalisis batas tingkat kerusakan telur}

\section{Peta Kendali P (P-Chart)}

Dalam menganalisis tujuan kedua mengenai batas kendali menggunakan peta kendali $\mathrm{p}$ ( $p$-chart) sebagai alat untuk pengendalian proses secara statistik.

\section{Menghitung Persentase Kerusakan (p)}

$$
\mathrm{p}=\frac{\mathrm{np}}{\mathrm{n}}
$$

Keterangan :

$\mathrm{np}:$ jumlah gagal dalam subgrup $(\mathrm{kg})$

$\mathrm{n}$ : jumlah yang diperiksa dalam subgrup $(\mathrm{kg})$

\section{Menghitung garis pusat atau central line $(\mathrm{CL})$}

$$
\mathrm{CL}=\overline{\mathrm{p}}=\frac{\Sigma \mathrm{np}}{\Sigma \mathrm{n}}
$$

Keterangan :

$\Sigma \mathrm{np}$ : jumlah total yang rusak $(\mathrm{kg})$

$\Sigma \mathrm{n}$ : jumlah total yang diperiksa $(\mathrm{kg})$

Menghitung batas kendali atas atau Upper Control Limit (UCL)

$$
\mathrm{UCL}=\overline{\mathrm{p}}+3 \sqrt{\frac{\overline{\mathrm{p}}(1-\overline{\mathrm{p}})}{\mathrm{n}}}
$$


Keterangan :

$\overline{\mathrm{p}}$ : rata-rata ketidak sesuaian produk $(\mathrm{kg})$

$\mathrm{n} \quad$ : jumlah produksi $(\mathrm{kg})$

Menghitung batas kendali bawah atau Lower Control Limit (LCL)

$\mathrm{UCL}=\overline{\mathrm{p}}-3 \sqrt{\frac{\overline{\mathrm{p}}(1-\overline{\mathrm{p}})}{\mathrm{n}}}$

Keterangan :

$\overline{\mathrm{p}} \quad$ : rata-rata ketidak sesuaian produk $(\mathrm{kg})$

$\mathrm{n} \quad$ : jumlah produksi $(\mathrm{kg})$

\section{Mendeskripsikan faktor-faktor yang menyebabkan kerusakan telur ayam}

\section{Diagram Tulang Ikan (Fishbone Diagram)}

Setelah diperoleh data dari Persada Farm dan mengetahui faktor pernyebab masalah yang paling dominan, maka dilakukan analisis menggunakan fishbone diagram. Diagram sebab-akibat berguna untuk mengidentifikasi masalah kerusakan produk paling dominan. Faktor penyebab utama dalam masalah ini antara lain man, work methods, machinelequipment, raw material, dan work environment. Setelah mengetahui faktor kerusakan terlur yang terjadi, maka perlunya mengambil langkah-langka perbaikan untuk mencegah timbulnya kerusakan yang serupa, berguna untuk mempertahankan produksi telur yang sesuai denga standar kualitas yang dibutuhkan.

\section{HASIL PENELITIAN DAN PEMBAHASAN}

\section{Mengetahui tingkat kerusakan dominan pada produk telur ayam}

Pengendalian tingkat kerusakan secara statistik, langkah pertama yang dilakukan adalah membuat check sheet. Check sheet bertujuan untuk mempermudah proses pengumpulan data sehingga data dapat dibuat lebih spesifik antara jenis dan jumlah kerusakan produk telur ayam. Sejalan dengan penelitian (Choir, 2018) yang mengatakan bahwa Pembuatan tabel lembar pemeriksaan (check sheet) ini berguna untuk mempermudah proses pengumpulan data serta analisis. Berikut merupakan hasil pengumpulan data jumlah produksi telur, dan jumlah produk telur yang rusak di Persada Farm, sebagai berikut : 
Kuswardani et.al., Analisis Pengendalian Kualitas Produk Telur Di Persada Farm..

Tabel 1. Lembar Pemeriksaan (Check Sheet) Jumlah Produk dan Jumlah Produk Rusak di Persada Farm

\begin{tabular}{|c|c|c|c|c|c|c|}
\hline \multirow[b]{2}{*}{ Bulan } & \multirow{2}{*}{$\begin{array}{c}\text { Jumlah } \\
\text { Produk } \\
\text { Telur (kg) }\end{array}$} & \multicolumn{3}{|c|}{ Jenis Produk } & \multirow{2}{*}{$\begin{array}{c}\text { Jumlah } \\
\text { Produk } \\
\text { Telur } \\
\text { Rusak (kg) }\end{array}$} & \multirow{2}{*}{$\begin{array}{l}\text { Persentase } \\
\text { Produk } \\
\text { Telur } \\
\text { Rusak (\%) }\end{array}$} \\
\hline & & $\begin{array}{c}\text { Telur } \\
\text { Retak } \\
\text { (kg) }\end{array}$ & $\begin{array}{c}\text { Telur } \\
\text { Pecah } \\
(\text { kg) }\end{array}$ & $\begin{array}{c}\text { Telur } \\
\text { Putih } \\
\text { (kg) }\end{array}$ & & \\
\hline Aug-18 & $572.618,00$ & $5.318,90$ & $5.041,55$ & $18.806,35$ & $29.166,80$ & 5,09 \\
\hline Sep-18 & $569.645,00$ & $5.717,30$ & $4.799,00$ & $18.808,25$ & $29.224,55$ & 5,13 \\
\hline Oct-18 & $616, .79,00$ & $5.636,05$ & $4.469,00$ & $19.860,20$ & $29.965,25$ & 4,86 \\
\hline Nov-18 & $608.302,00$ & $5.460,90$ & $3.381,70$ & $19.829,10$ & $28.671,70$ & 4,71 \\
\hline Dec-18 & $646.978,00$ & $5.434,70$ & $3.868,50$ & $20.703,40$ & $30.006,60$ & 4,64 \\
\hline Jan-19 & $650.331,00$ & $5.334,35$ & $4.783,30$ & $22.469,30$ & $32.586,95$ & 5,01 \\
\hline Feb-19 & $555.355,00$ & $4.574,00$ & $5.085,25$ & $26.041,90$ & $35.701,15$ & 6,43 \\
\hline Mar-19 & $580.441,00$ & $4.323,30$ & $5.742,20$ & $20.098,10$ & $30.163,60$ & 5,20 \\
\hline Apr-19 & $515.297,00$ & $5.724,00$ & $5.372,30$ & $20.351,00$ & $31.447,30$ & 6,10 \\
\hline May-19 & $500.009,00$ & $4.683,40$ & $5.405,40$ & $18.462,74$ & $28.551,54$ & 5,71 \\
\hline Jun-19 & $494.615,00$ & $4.775,40$ & $4.320,10$ & $17.950,36$ & $27.045,86$ & 5,47 \\
\hline Jul-19 & $596.443,00$ & $2.990,90$ & $5.311,90$ & $11.662,90$ & $19.965,70$ & 3,35 \\
\hline Rata-rata & $\mathbf{5 7 5 . 5 1 7 , 7 5}$ & $4.997,77$ & $4.798,35$ & $19.586,97$ & $29.374,75$ & 5,14 \\
\hline Total & $6.906 .213,00$ & $59.973,20$ & $57.580,20$ & $235.043,60$ & $352.497,00$ & 5,10 \\
\hline
\end{tabular}

Sumber : Analisis Data Sekunder, 2019

Berdasarkan Tabel 1 memperlihatkan bahwa data jumlah produk telur pada periode Bulan Agustus 2018 - Juli 2019 yaitu sebanyak $6.906 .213 \mathrm{~kg}$. Jumlah dan jenis produk rusak yaitu telur retak 59.973,20 kg dengan persentase sebesar $0,87 \%$, telur pecah $57.580,20 \mathrm{~kg}$ dengan persentase sebesar 0,83\%, dan telur putih 235.043,60 kg dengan persentase sebesar 3,4\%. Jumlah produk rusak keseluruhan sebanyak $352.497,00 \mathrm{~kg}$ dengan total presentasi produk rusak sebesar 5,10\%. Berdasarkan hasil analisis diketahui bahwa pada periode Bulan Agustus 2018 - Juli 2019 jumlah produk telur rusak terdapat 8 bulan yang melebihi standar yang ditetapkan oleh perusahaan sebesar 5\% dan kerusakan produk pada telur putih lebih dominan daripada kerusakan pada telur retak dan telur pecah. 
Persada Farm telah menetapakn standar tingkat kerusakan telur yang ditetapkan sebesar 5\% yang terdiri dari produk telur putih, telur retak dan telur pecah dengan standar tersebut Persada Farm dapat menekan atau mengurangi volume kerusakan, menjaga atau menaikan kualitas, meminimalisir kerugian, meningkatkan keuntungan dan menjaga atau menaikan comporate image. Tingginya angka kerusakan produk menjadi sebuah kerugian bagi perusahaan karena akan menambah beban finansial berupa biaya perbaikan produk telur yang rusak. Dikatakan demikian karena pada hasil penelitian total persentaase produk rusak sebesar 5,10\% yang berarti tingkat kerusakan produk telur ayam dikategorikan tinggi, sehingga dapat dikatakan kerusakan produk berada diluar batas kendali.

Histogram merupakan tabulasi data yang diatur berdasarkan ukurannya, hal ini bertujuan untuk memudahkan dalam melihat lebih jelas produk cacar/reject yang terjadi sesuai dengan tabel, maka disajikan ke histogram yaitu dalam bentuk grafik balok (Andespa, 2019). Berikut ini merupakan gambar diagram histogram jenis dan jumlah produk telur rusak Bulan Agustus 2018 - Juli 2019 di Persada Farm :



Gambar 1. Grafik Batang Jenis dan Jumlah Produk Telur Rusak

Berdasarkan diagram histogram, diketahui bahwa pada Bulan Agustus 2018 - Juli 2019 terdapat beberapa produk telur rusak diantaranya total telur retak $59.973,20 \mathrm{~kg}$ dengan persentase sebesar $0,87 \%$, total telur pecah $57.580,20 \mathrm{~kg}$ dengan persentase sebesar $0,83 \%$, dan total telur putih 235.043,60 kg dengan persentase sebesar 3,4\%. Telur putih merupakan 
Kuswardani et.al., Analisis Pengendalian Kualitas Produk Telur Di Persada Farm..

produk telur rusak yang paling dominan, sedangkan produk telur rusak yang paling sedikit adalah telur pecah.Berikut ini merupakan tabel dari jumlah kerusakan selama periode Bulan Agustus 2018 - Juli 2019 :

Tabel 2. Jenis, Jumlah dan Peresentase Produk Telur Rusak Bulan Agustus 2018 - Juli 2019

\begin{tabular}{lrrr}
\hline $\begin{array}{c}\text { Jenis Kerusakan } \\
\text { Telur }\end{array}$ & $\begin{array}{c}\text { Jumlah Kerusakan } \\
\text { Telur (kg) }\end{array}$ & $\begin{array}{c}\text { Peresentase } \\
(\%)\end{array}$ & $\begin{array}{c}\text { Peresentase } \\
\text { Kumulatif }(\%)\end{array}$ \\
\hline Telur Putih & $235.043,60$ & 67 & 67 \\
Telur Retak & $59.973,20$ & 17 & 84 \\
Telur Pecah & $57.580,20$ & 16 & 100 \\
\hline Total & $352.597,00$ & 100 & \\
\hline
\end{tabular}

Sumber : Analisis Data Sekunder, 2019

Berdasarkan Tabel 2, maka dapat diolah menjadi Diagram Pareto yang dimaksudkan agar informasi yang diperoleh lebih jelas. Diagram Pereto dibuat dalam bentuk diagram, berikut ini adalah gambar Diagram Pareto jumlah dan jenis produk telur rusak pada periode Bulan Agustus 2018 - Juli 2019 :

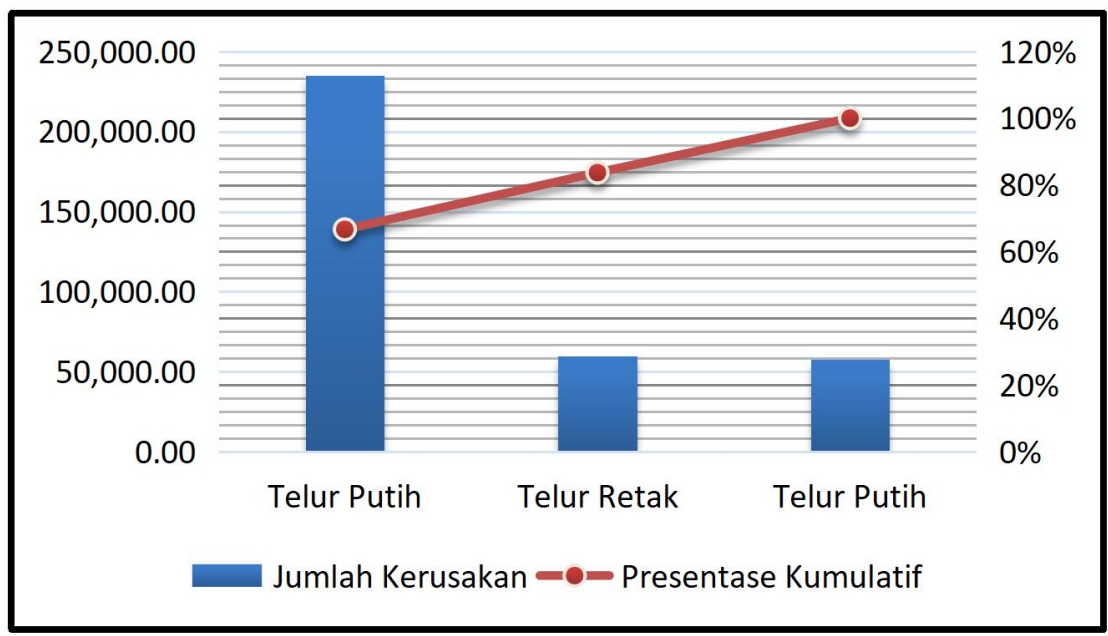

Gambar 2. Diagram Pareto Kerusakan Produk Telur Periode

Diagram pareto digunakan untuk menentukan skala prioritas, dalam konteks penelitian tentang pengendalian produk cacat, maka prioritas yang dimaksud adalah jenis kecacatan yang memiliki persentase kumulatif $70 \%$ 
(Purnomo dan Lilia, 2018). Berdasarkan Gambar 2, diketahui bahwa jenis produk rusak yaitu kerusakan telur pada periode Bulan Agustus 2018 - Juli 2019 sangat dominan. Jumlah persentase dari jenis telur putih 67\%; telur retak $17 \%$ dan telur pecah $16 \%$. Faktor penyebab cangkang telur putih dipengaruhi oleh faktor asupan nutrisi, kondisi lingkungan, umur ayam, dan penyakit yang dapat berpengaruh terhadap cangkang telur. Berdasarkan akumulasi data diatas maka dapat disimpulkan bahwa fokus untuk melakukan pengecekan produksi telur ayam dan perbaikan dari segi manajemen (kondisi pakan, kondisi lingkungan, umur ayam, dan penyakit) supaya dapat memperkecil terjadinya kerusakan produk telur ayam.

\section{Menganalisis Batas Kendali Tingkat Kerusakan Produk di Persada Farm}

Peta kendali p mempunyai manfaat untuk membantu pengendalian kualitas produksi serta dapat memberikan informasi mengenai kapan dan dimana perusahaan harus melakukan perbaikan kualitas (Mahid dkk, 2018). Berikut merupakan hasil pengolahan dara untuk pembuatan peta kendali $\mathrm{p}$ kerusakan produk telur pada Tabel 3, sebagai berikut :

Tabel 3. Perhitungan Peta Kendali P Periode Bulan Agustus 2018 - Juli 2019

\begin{tabular}{|c|c|c|c|c|c|c|c|}
\hline Bulan & np & $\mathbf{n}$ & $\mathbf{p}$ & p_bar & UCL & $\mathbf{L C L}$ & Keterangan \\
\hline Aug-18 & $29.166,80$ & $572.618,00$ & 0,0509 & 0,051 & 0,052 & 0,050 & Terkontrol \\
\hline Sep-18 & $29.224,55$ & $569.645,00$ & 0,0513 & 0,051 & 0,052 & 0,050 & Terkontrol \\
\hline Oct-18 & $29.965,25$ & $616.179,00$ & 0,0486 & 0,051 & 0,052 & 0,050 & Tidak Terkontrol \\
\hline Nov-18 & $28.671,70$ & $608.302,00$ & 0,0471 & 0,051 & 0,052 & 0,050 & Tidak Terkontrol \\
\hline Dec-18 & $30.006,60$ & $646.978,00$ & 0,0464 & 0,051 & 0,052 & 0,050 & Tidak Terkontrol \\
\hline Jan-19 & $32.586,95$ & $650.331,00$ & 0,0501 & 0,051 & 0,052 & 0,050 & Terkontrol \\
\hline Feb-19 & $35.701,15$ & $555.355,00$ & 0,0643 & 0,051 & 0,052 & 0,050 & Tidak Terkontrol \\
\hline Mar-19 & $30.163,60$ & $580.441,00$ & 0,0520 & 0,051 & 0,052 & 0,050 & Terkontrol \\
\hline Apr-19 & $31.447,30$ & $515.297,00$ & 0,0610 & 0,051 & 0,052 & 0,050 & Tidak Terkontrol \\
\hline May-19 & $28.551,54$ & $500.009,00$ & 0,0571 & 0,051 & 0,052 & 0,050 & Tidak Terkontrol \\
\hline Jun-19 & $27.045,86$ & $494.615,00$ & 0,0547 & 0,051 & 0,052 & 0,050 & Tidak Terkontrol \\
\hline Jul-19 & $19.965,70$ & $596.443,00$ & 0,0335 & 0,051 & 0,052 & 0,050 & Tidak Terkontrol \\
\hline$\Sigma$ & $352.497,00$ & $6.906 .213,00$ & & & & & \\
\hline
\end{tabular}

Sumber : Analisis Data Sekunder, 2019 
Kuswardani et.al., Analisis Pengendalian Kualitas Produk Telur Di Persada Farm..

Dengan perhitungan tersebut, selanjutnya membuat grafik peta kendali $\mathrm{p}$ dengan menggunakan Microsoft Excel dan didapati hasil sebagai berikut :

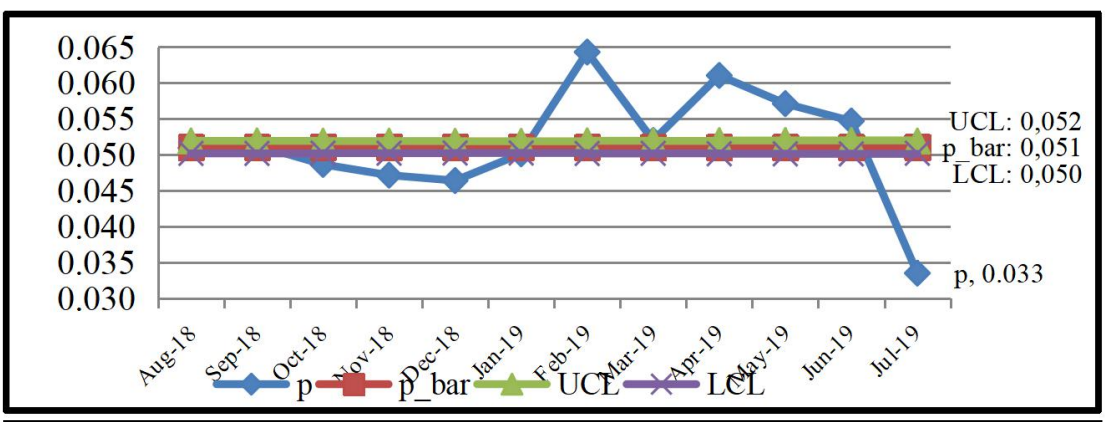

Gambar 3. Grafik Peta Kendali P Produk Telur

Berdasarkan Gambar 3, diketahui bahwa data yang diperoleh tidak seluruhnya berada dalam batas kendali, Pola titik - titik dalam peta kendali berfluktuasi dan tidak beraturan. Dari 12 bulan hanya terdapat 4 bulan yang berada didalam batas kendali dan terdapat 8 bulan yang berada diluar batas kendali. Pada Bulan Oktober, November, Desember, dan Juli berada diluar batas kendali LCL sedangkan pada Bulan Februari, April, Maret, dan Juni berada diluar batas kendali UCL. Hal ini menunjukkan terjadinya penyimpangan dan dalam pengendalian tingkat kerusakan di Persada Farm karena dari jumlah tingkat kerusakan produk telur sebesar $66 \%$ yang melebihi dari batas kendali perusahaan sebesar $5 \%$.

Karena adanya titik berfluktuasi yang tinggi dan tidak beraturan yang menunjukan bahwa proses produksi masih mengalami penyimpangan. Sejalan dengan penelitian Yani (2018) yang mengatakan bahwa pengendalian kualitas memerlukan adanya perbaikan karena adanya titik berfluktuasi dan tidak beraturan uang menunjukan bahwa proses produksi masih mengalami penyimpangan. Hal ini dapat terjadi karena kelalaian dan ketidakdisiplanan karyawan. Kerusakan kandang dan tempat pakan yang masih tetap digunakan untuk proses produksi. Sejalan dengan penelitian Arifianti (2013) yang mengatakan bahwa selama pengukuran sampel berada diluar batas pengendalialian, maka proses disitu dihentikan dan dicari penyebabnnya. 
Pengendalian tingkat kerusakan produk telur di Persada Farm memerlukan adanya perbaikan dan pengawasan kepada para pekerja agar dapat melakukan seluruh rangkaian proses produksi dengan efektif dan efisien seperti umur ayam yang sudah afkir sebaiknya langsung dijual dan tidak diukur dengan hasil produksi agar dapat mengurangi jumlah ayam afkir untuk mengendalikan kerusakan produk telur yang disebabkan ayam afkir.. Karena jumlah tingkat kerusakan produk telur sebesar 66\% yang melebihi dari batas kendali. Akan tetapi, adanya beberapa titik berfluktuasi yang tinggi dan tidak beraturan yang menunjukan bahwa proses produksi masih mengalami penyimpangan.

\section{Mendeskripsikan faktor-faktor yang menyebabkan kerusakan telur ayam}

Diagram sebab-akibat (Fishbone) bertujuan untuk mengetahui penyebab permasalahan yang terjadi dan faktor-faktor yang menyebabkan permasalahan itu terjadi. Faktor tersebut merupakan salah satu indikasi yang menyebabkan menurunnya tingkat kualitas telur ayam. Faktor-faktor penyebab utama dalam permasalahan tersebut adalah manusia (man), metode (method), mesin (machine), bahan baku (materials), dan lingkungan (environment). Berdasarkan faktor-faktor penyebab permasalahan diatas maka Persada Farm perlu mengetahui dimana letak faktor-faktor yang menjadi penyebab permasalahan dan harus dilakukan perbaikan. Berikut ini adalah analisis diagram sebab-akibat periode Bulan Agustus 2018 - Juli 2019:

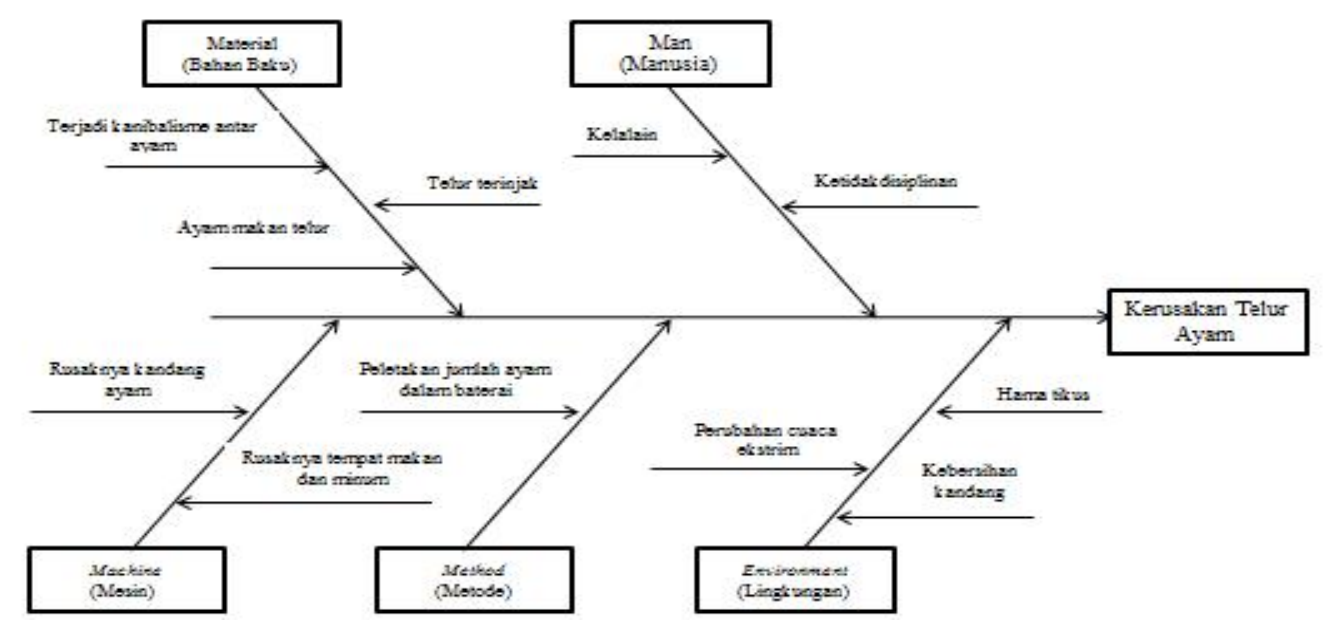

Gambar 4. Diagram Tulang Ikan (Fishbone) 
Kuswardani et.al., Analisis Pengendalian Kualitas Produk Telur Di Persada Farm..

Berdasarkan Gambar 4 diketahui bahwa terdapat beberapa permasalahan dalam proses produksi telur ayam di Persada Farm yang mengakibatkan proses produksi tidak sesuaidengan spesifikasi yang telah ditetapkan perusahaan. Faktorfaktor yang menyebabkan kerusakan produk yaitu manusia (man), metode (method), mesin (machine), bahan baku (materials), dan lingkungan (environment). Berdasarkan hasil analisis, terdapat beberapa faktor penyebab terjadinya permasalahan pada proses produksi telur ayam yang mengakibatkan kerusakan pada produk telur ayam. Faktor-faktor yang berperngaruh terhadap permasalah tersebut adalah sebagai berikut :

\section{Faktor manusia (man)}

karyawan yang terlibat dalam proses produksi telur ayam di Persada Farm. faktor manusia yang menjadi penyebab permasalahan antara lain kelalaian dan ketidakdisiplinan dari karyawan. Kelalaian karyawan dalam keterlambatan pengambian telur dapat mengakibatkan telur oleh ayam dan telur dapat dimakan oleh ayam, keterlambatan pada pengambilan ayam afkir mengakibatkan penurunan produktifitas produksi telur ayam, keterlambatan pengambilan ayam mati didalam baterai dapat mengakibatkan tubuh ayam yang mati dipatok oleh ayam lainnya dan keterlambatnya pemberian pakan yang menyebabkan ayam kehabisan makan dan minum, adapun faktor lain yaitu pakan ayam yang dimakan oleh hama tikus, keterlambatan pemberian vaksin yang menyebabkan ayam gampang terserang oleh penyakit terutama virus.

Faktor ketidakdisplinan karyawan yaitu sedikit bekerja tetapi meminta gaji besar, yang berarti para karyawan yang terburu-buru saat pengambilan telur hingga menimbulkan kegaduhan yang dapat memicu ayam menjadi stres, proses pembersihan telur yang kurang bersih bila tidak teliti akan merusak cangkang telur, dan saat packging pekerja terburu-buru dalam menyusun telur sehingga menyebabkan telur retak dan telur pecah. Dari hasil tersebut disimpulkan bahwa faktor manusia memiliki pengaruh besar dalam proses produksi telur ayam dan memerlukan tindakan yang cepat dalam melakukan penanganan terhadap budidaya ayam petelur apabila terjadi penyimpangan dalam proses produksi telur petelur karena dapat berakibat menurunnya kualitas produk pada telur ayam. 
Jurnal Dinamika Sosisal Ekonomi, 21 (2) : 105-121

\section{Faktor metode (method)}

Intruksi kerja atau perintah kerja yang harus diikuti dalam proses produksi telur ayam di Persada Farm. Dalam faktor metode adalah kurangnya koordinasi pada cara peletakan jumlah ayam dalam 1 baterai yang seharusnya diletakan maksima 2 ekor ayam akan tetapi diletakan menjadi 3 ekor ayam. Hal ini dapat menyebabkan tingkat kanibalisme antar ayam dan tingkat kerusakan pada telur yang mudah terinjak dan telur mudah dipatuk/dimakan oleh ayam. Proses pencampuran pakan ternak yang tidak merata dapat mengakibatkan proses produktifitas menurun karna kandungan nutrisi pakan ayam yang tidak seimbang. Persada Farm melakukan koordinasi dengan karyawan agar melakukan perubahan metode yang lebih efektif dengan cara peletakan jumlah ayam dalam 1 baterai sebaiknya maksimal diisikan 2 ekor ayam agar dapat memudahkan untuk mengontrol kondisi ayam, ayam terhindar dari stres, terhindar dari kanibalisme antar ayam, mendapatkan oksigen yang cukup dan telur tidak mudah terinjak oleh ayam.

\section{Faktor mesin (machine)}

Berbagai peralatan yang digunakan dalam proses produksi telur ayam di Persada Farm. Dalam faktor mesin adalah rusaknya kandang ayam, rusaknya tempat makan dan minum. Dengan kondisi kawat baterai yang rusak. Kerusakan pada kawat baterai ini bisa karena umur kawat yang sudah lama atau karena kualitas kawat yang memang rendah. Di Indonesia banyak beredar kawat baterai yang memiliki harga dan kualitas yang bervariasi. Kadang peternak hanya mempertimbangkan harga murah untuk memilih kawat baterai tetapi ternyata mudah rusak dan mudah berkarat. Sehingga kerusakan cangkang telur murni karena akibat fisik terkena kawat yang rusak. Sedangkan rusaknya temmpat makan yang sebagian tidak layak pakai tetapi masih tetap digunakan untuk menampung pakan ayam berakibat banyak pakan yang tumpah sehingga kurangnya nutrisi pada ayam dan berdampak pada ketebalan cangkang telur. Hal ini dapat berdampak pada psikologi ayam yang tidak baik dan ayam mudah stres yang mengakibatkan penuruan produksi telur. Sudut kemiriangan kandang baterai yang kurang sehingga terdapat telur yang tertahan didalam kandang sehingga telur 
Kuswardani et.al., Analisis Pengendalian Kualitas Produk Telur Di Persada Farm..

dapat oleh ayam dan menyebabkan keretakan hingga pecah. Supaya memperbaiki dalam pembangunan pembuatan kandang baterai harus memperhatikan ukuran, sudut kemiringan kandang yang sesuai dan perbaikan pada tempat makan ayam yang sudah rusak agar tidak ada penyimpangan yang terjadi

\section{Faktor bahan baku (materials)}

Ayam yang digunakan oleh Persada Farm sebagai bahan baku dalam proses produksi telur ayam. Dalam faktor bahan baku yang menjadi penyebab terjadinya kerusakan telur ayam di Persada Farm adalah terjadinya telur terinjak, kanibalisme antar ayam dan ayam makan telur. Telur terinjak karena sudut kemiringan dari kandang baterai kurang berakibat telur tertahan didalam kandang dan dapat terinjak oleh ayam yang menyebabkan telur menjadi retak hingga pecah. Kanibalisme antar ayam dalam pemberian jumlah pakan yang tidak merata dan jumlah ayam dalam 1 baterai lebih dari 2 ekor ayam, sehingga ayam menjadi lebih agresif dan mudah stres. Ayam makan telur disebabkan karena telur terlalu lama berada didalam kandang baterai dan pemberian pakan yang kurang berakibat ayam lebih agresif dan menyebabkan ayam mematuk telur hingga retak atau pecah. Hal ini terjadi karena kelalaian karyawan dalam bekerja merawat ayam tersebut. Supaya dapat memperbaiki permasalahan yang terjadi maka karyawan memperbaiki mengenai jumlah ayam dalam baterai dan pemberian pakan agar mengurangi kanibalisme antar ayam, telur terinjak dan ayam memakan telur sehingga dapat mengurangi terjadinya kerusakan pada telur.

\section{Faktor lingkungan (environment)}

Keadaan sekitar perusahaan secara langsung maupun tidak langsung yang dapat mempengaruhi proses produksi telur ayam di Persada Farm. Pada faktor lingkungan yang menjadi faktor penyebab kerusakan produk telur ayam di Persada Farm adalah hama tikus, cuaca yang ekstrim, dan kebersihan kandang. Hama tikus dapat menyebabkan jumlah pakan yang diberikan kepada ayam berkurang hal ini berdampak pada kerusakan terlur dan kematian ayam. Sedangan akibat dari cuaca ekstrim berdampak ayam menjadi stres akibat cuaca panas, menyebabkan ayam lebih banyak minum dan mengurangi aktivitas konsumsi ransum sehingga kebutuhan nutrisi untuk pembentukan telur tidak terpenuhi. 
Kebersihan kandang yang kurang diperhatikan kondisi ini dapat menyebabkan produksi telur turun kualitasnya dan ayam mudah terjangkit oleh penyakit dan virus. Supaya dapat memperbaiki permasalahan-permasalahan yang terjadi maka harus dilakukan pembersihan dan sanitasi kandang. Hal ini disarankan supaya membuat lingkungan kandang ayam lebih terjaga dari hama, kondisi ayam tidak mudah stres dan tidak mudah terserang penyakit.

\section{KESIMPULAN DAN SARAN}

\section{Kesimpulan}

Tingkat kerusakan produk yang paling dominan yang terjadi pada produk telur ayam di Persada Farm yaitu produk telur putih dengan total persentase telur putih sebesar 3,4\%. Pengendalian tingkat kerusakan produk telur yang dilakukan Persada Farm berada diluar batas kendali karena jumlah tingkat kerusakan telur melebihi dari batas kendali perusahaan sebesar 5\%. Manusia (kelalaian dan ketidakdisiplinan karyawan), metode (meletakkan jumlah ayam dalam kandang baterai), mesin (kandang ayam tidak cocok untuk digunakan dan tempat pakan rusak), bahan baku (telur diinjak oleh ayam, kanibal antara ayam, ayam memakan telur) dan lingkungan (hama tikus, perubahan cuaca dan kebersihan kandang) adalah faktor yang mempengaruhi kerusakan telur ayam.

\section{Saran}

Perusahaan diharapkan melakukan perbaikan dan pengawasan kepada para pekerja agar dapat melakukan seluruh rangkaian proses produksi dengan efektif dan efisien seperti pembuatan kandang baterai harus memperhatikan ukuran, sudut kemiringan kandang yang sesuai, dan perbaikan pada tempat makan ayam yang sudah rusak agar tidak ada penyimpangan yang terjadi. Karyawan lebih teliti dalam melakukan pengecekan produksi telur dan memperbaiki dari segi manajemen (kondisi pakan, kondisi lingkungan, umur ayam, dan penyakit) agar dapat memperkecil terjadinya kerusakan produk telur ayam. 
Kuswardani et.al., Analisis Pengendalian Kualitas Produk Telur Di Persada Farm..

\section{DAFTAR PUSTAKA}

Andespa, Ira. (2019). Analisis Pengendalian Mutu Dengan Menggunakan Statistical Quality Control (SQC) Pada PT.Pratama Abadi Industri (JX) Sukabumi. Jurnal Ekonomi dan Bisnis, 9(2), 129-160.

Arifianti, Ria. (2013). Analisis Kualitas Produk Sepatu Tomkins. Jurnal Dinamika Manajemen, 1(4), 46-58

Choir, Fikron Al. (2018). Pelaksanaan Quality Control Produksi Untuk Mencapau Kualitas Produk Yang Meningkat(Studi Kasus PT. Gaya Indah Kharisma Kota Tangerang). Jurnal Manajemen Pemasaran, 4(1), 1-20.

Ginting, Rosnani. (2007). Sistem Produksi. Edisi Pertama. Yogyakarta: Graha Ilmu

Mahid D. A, Saharuddin K, Syamsuddin. (2018). Analisis Pengendalian Kualitas Produk Telur Ayam Pada UD Amina Kelurahan Petobo di Kota Palu. Jurnal Ilmu Manajemen, 4(3), 271-280.

Purnomo, Heri dan Lilia P.R. (2018). Analisis Pengendalian Produk Cacat Dengan Metode Four Quality Control (4QC) Tools. Jurnal Akademika, 1 (16) $75-81$

Yani, Ari Soeti. (2018). Analisis Pengawasan Kualitas Produk Dengan Menggunakan Metode P-Chart Untuk Meminimalkan Tingkat Kerusakan Produk Pada UKM Sepatu. Jurnal For Business and Enterpreneur, 2(1), 54-64. 